\title{
Improving the Self-Esteem in Postpartum Women Through Massage and Complementary Techniques
}

\author{
Mârza-Dănilă Doina ${ }^{1 *}$ \\ Mârza-Dănilă Dănuț Nicu² \\ 1,2 "Vasile Alecsandri" University of Bacău, 157, Calea Mărășești, 600115, Romania
}

Keywords: massage, Shiatsu, stretching, postpartum women, self-esteem

\begin{abstract}
We thought that we could approach the postpartum woman, from a psychological-physical point of view, through massage, applying programs adapted to the specific needs of four postpartum women, the results being compared to the progress of other four postpartum women, who were not involved in these programs, being tested only initially and finally. The results have proven that the application of adapted massage, Shiatsu, and stretching programs on postpartum women over the course of the first eight weeks after birth (three sessions per week during the first four weeks, and two sessions per week during the following four) contributes to the acceleration of the process of returning to normal physical and emotional parameters and to the improvement of their self-esteem, successfully preventing the postnatal depression.
\end{abstract}

\section{Introduction}

Once the baby is born, the woman's status is suddenly changed, finding herself facing new challenges and being in the situation where she has to offer unconditional love and affection to her child, responding to the child's need for dependence. For a successful adaptation to the new situation, the mother needs support and mental balance. Once this sudden change happened, the woman is completely taken in by her role as mother, and does not find the time, during the postpartum period, for her role as woman, wife, daughter, friend, etc. For these reasons, "the new mother needs emotional support from her family and husband and from health care specialists, in order for her to be able to go through this period and to be in an optimal state that would allow her to respond appropriately to her own needs and the ones of her child and family" (Niţescu, 2010, p. 105).

The birth of a child represents a total change of the priorities, the child stepping into the forefront of the family life, becoming the mother's main preoccupation. It is good that the husband assumes a part of the responsibilities regarding the child care and support the mother, so that she could have time for

\footnotetext{
*E-mail: doinamarza57@gmail.com
} 
herself and feel important, taking care of herself. If the mother is the only carer for the child, in a short time she will end up feeling exhausted and unsupported.

The postpartum is a period of bonding between mother and child, during which the foundations for their relationship are laid. That is why the mother's mental balance is important, because the child can feel her emotional states and can react accordingly. "If the mother is going through a period of emotional instability, the child will be anxious and will develop a series of health and emotional issues" (Munteanu, 2000, p. 123). This period is characterized by a process of returning to the normal physical and emotional parameters that have changed over the course of the pregnancy. After birth, because of the physical modifications occurred during the pregnancy, the mother's self-esteem is diminished, this contributing considerably to the postnatal depression.

Studies regarding the postpartum rehabilitation proved that "the use of massage in the first postnatal 8 weeks resulted in muscle relaxation, an improvement of blood and lymphatic circulation, stress reduction, pain diminishing, a reduction of adipose tissue, improvement of skin elasticity and hormonal regulation (a decrease in the quantity of estrogen and progesterone, and of cortisole, an increase in the quantity of oxytocine, a reduction of dopamine and serotonin, associated with depression, the balance of adrenaline and noradrenaline" (Obstrone, 2012).

\section{Material and methods}

This research started from the hypothesis stating that the use of massage, of Shiatsu, and of stretching can contribute to the acceleration of the recovery process, returning to the normal mental-physical parameters, including rebuilding the selfesteem and preventing the postpartum depression.

The study comprised 8 postpartum women, aged between 25 and 35, who gave normal births; 4 of them benefited from massage, Shiatsu and stretching sessions, while the other 4 were only tested initially and finally, in order to compare the results.

In order to assess the mental-physical functional status of the postpartum women, the following tests were used, initially and finally: the Vass scale, the Hettinger test, the measurement of the body weight, the calculation of the Body Mass Index, and the Self-esteem Questionnaire (ETES - L'Echelle Toulousaine d'Estime de Soi) (Mruk, 2006, p. 51).

The postpartum women in the experimental group have benefited in the first 4 weeks of 3 adapted sessions of massage, Shiatsu and stretching per week, and in the following 4 weeks, of 2 sessions per week, each with a duration of approximately 40-50 minutes.

\section{Results and Discussions}

In order to present the results, the average scores for the subjects in both groups were calculated, so that a comparison can be possible. 
Table 1. Initial and final results for the visual and palpatory examinations of the subjects

\begin{tabular}{|c|c|c|c|c|c|}
\hline \multirow{2}{*}{$\begin{array}{l}\text { Examined } \\
\text { structure }\end{array}$} & \multirow{2}{*}{$\begin{array}{c}\text { Type of } \\
\text { examination }\end{array}$} & \multicolumn{2}{|c|}{$\begin{array}{c}\text { Experimental group } \\
\text { observations }\end{array}$} & \multicolumn{2}{|c|}{ Control group observations } \\
\hline & & Initial & Final & Initial & Final \\
\hline \multirow[t]{2}{*}{$\begin{array}{l}\text { The skin } \\
\text { and the } \\
\text { subcutaneo } \\
\text { us tissue }\end{array}$} & $\begin{array}{c}\text { Visual } \\
\text { examination }\end{array}$ & $\begin{array}{l}\text { Pale skin, } \\
\text { with stretch } \\
\text { marks } \\
\text { Subcutaneo } \\
\text { us adipose } \\
\text { tissue }\end{array}$ & $\begin{array}{l}\text { Normal } \\
\text { looking skin, } \\
\text { reduced } \\
\text { stretch marks, } \\
\text { reduced } \\
\text { adipose tissue }\end{array}$ & $\begin{array}{c}\text { Pale skin, } \\
\text { with stretch } \\
\text { marks } \\
\text { Subcutaneo } \\
\text { us adipose } \\
\text { tissue }\end{array}$ & $\begin{array}{l}\text { Almost normal } \\
\text { looking skin, } \\
\text { stretch marks, } \\
\text { insignificantly } \\
\text { reduced adipose } \\
\text { tissue }\end{array}$ \\
\hline & $\begin{array}{c}\text { Palpatory } \\
\text { examination }\end{array}$ & $\begin{array}{c}\text { Dry, } \\
\text { sensitive, } \\
\text { flaccid skin }\end{array}$ & $\begin{array}{l}\text { Elastic skin, } \\
\text { with normal } \\
\text { sensitivity }\end{array}$ & $\begin{array}{c}\text { Dry, } \\
\text { sensitive, } \\
\text { flaccid skin }\end{array}$ & $\begin{array}{c}\text { Skin with } \\
\text { damaged } \\
\text { sensitivity, with } \\
\text { areas of hyper or } \\
\text { hyposensitivity }\end{array}$ \\
\hline \multirow[t]{3}{*}{$\begin{array}{c}\text { Muscle } \\
\text { tissue }\end{array}$} & $\begin{array}{c}\text { Visual } \\
\text { examination }\end{array}$ & $\begin{array}{c}\text { Normal } \\
\text { aspect }\end{array}$ & Normal aspect & $\begin{array}{c}\text { Normal } \\
\text { aspect }\end{array}$ & Normal aspect \\
\hline & $\begin{array}{c}\text { Palpatory } \\
\text { examination }\end{array}$ & $\begin{array}{c}\text { Hypotonic } \\
\text { abdominal } \\
\text { muscles }\end{array}$ & $\begin{array}{c}\text { Balanced } \\
\text { muscle tone }\end{array}$ & $\begin{array}{c}\text { Hypotonic } \\
\text { abdominal } \\
\text { muscles }\end{array}$ & $\begin{array}{l}\text { Hypotonic } \\
\text { abdominal } \\
\text { muscles }\end{array}$ \\
\hline & & $\begin{array}{l}\text { Hypertonic } \\
\text { lumbar } \\
\text { paravertebr } \\
\text { al muscles }\end{array}$ & & $\begin{array}{l}\text { Hypertonic } \\
\text { lumbar } \\
\text { paravertebra } \\
\text { l muscles }\end{array}$ & $\begin{array}{c}\text { Hypertonic } \\
\text { lumbar } \\
\text { paravertebral } \\
\text { muscles }\end{array}$ \\
\hline \multirow[t]{2}{*}{ Circulation } & $\begin{array}{c}\text { Visual } \\
\text { examination }\end{array}$ & $\begin{array}{l}\text { Incipient } \\
\text { varicose } \\
\text { veins and } \\
\text { edemas in } \\
\text { the lower } \\
\text { limbs }\end{array}$ & Normal aspect & $\begin{array}{l}\text { Incipient } \\
\text { varicose } \\
\text { veins and } \\
\text { edemas in } \\
\text { the limbs }\end{array}$ & $\begin{array}{l}\text { Still present } \\
\text { incipient } \\
\text { varicose veins }\end{array}$ \\
\hline & $\begin{array}{c}\text { Palpatory } \\
\text { examination }\end{array}$ & $\begin{array}{l}\text { Cold } \\
\text { extremities, } \\
\text { fovea sign } \\
\text { present }\end{array}$ & $\begin{array}{l}\text { Normal } \\
\text { temperature of } \\
\text { the } \\
\text { extremities, } \\
\text { no fovea sign }\end{array}$ & $\begin{array}{l}\text { Cold } \\
\text { extremities, } \\
\text { fovea sign } \\
\text { present }\end{array}$ & $\begin{array}{l}\text { Cold extremities, } \\
\text { fovea sign absent }\end{array}$ \\
\hline
\end{tabular}

As one can see in Table 1, in regards to the experimental group subjects, the massage, the shiatsu and the stretching have contributed to the normalization of the dysfunctional aspects that were initially identified in the examined structures, while in the control group subjects there was only a small degree of spontaneous rehabilitation, the remaining dysfunctions risking to become more severe or pathological. 


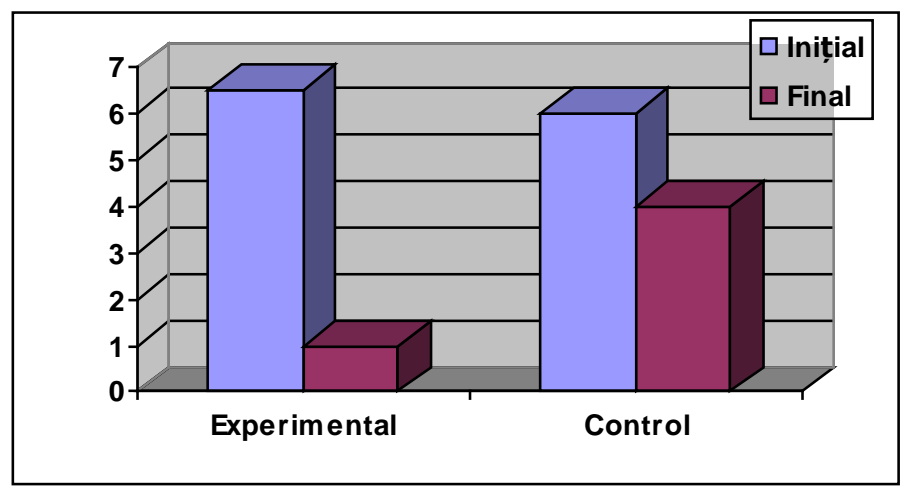

Figure 1. The progress of lumbar pain in the subjects from the two groups

In the experimental group subjects, the lumbar pain diminished close to zero, while in the control group subjects, at the end of the 8 weeks, the pain was still present (Fig.e 1).

Without benefiting from massage, shiatsu and stretching, the control group postpartum women regained their joint mobility, balance and muscle strength less so than the experimental group ones (Fig. 2, 3).

The body weight being an indicator that can contribute more to a low selfesteem, when the weight is above the desired limits, had a very good progress in the experimental group postpartum women, who have lost $13.5 \mathrm{~kg}$ in average, compared to the control group subjects, who have lost $6.5 \mathrm{~kg}$ in average, over the course of 8 weeks (Fig. 4). This situation was reflected also in the progress of the Body Mass Index (Fig. 5).

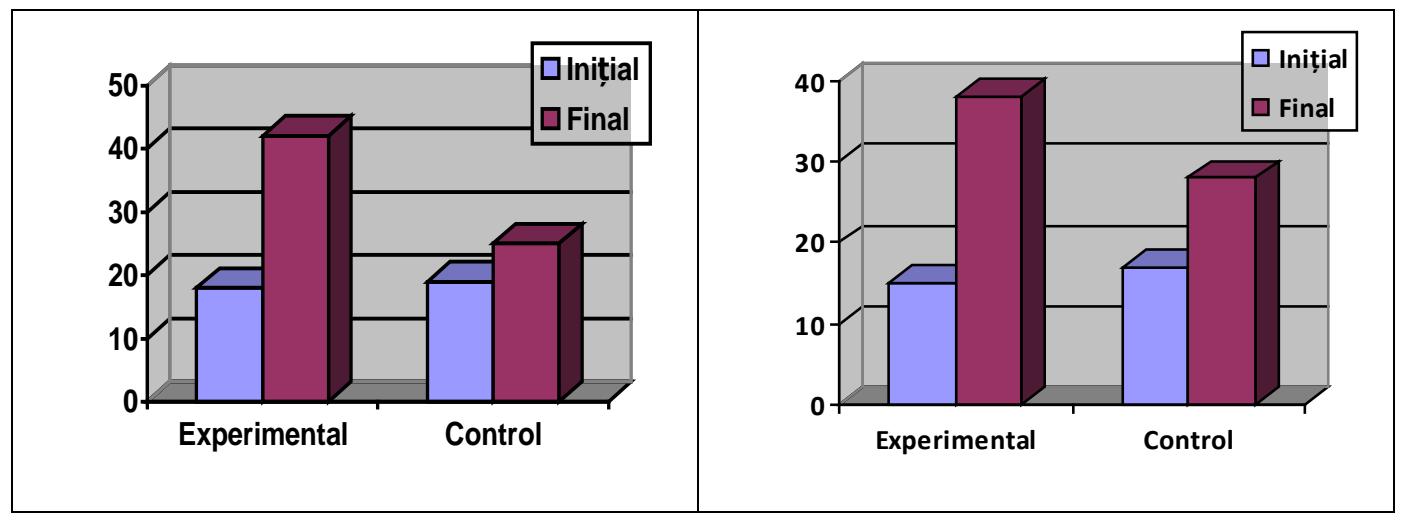

Figure 2. Progress of the average score recorded for joint mobility and balance
Figure 3. Progress of the average score recorded for muscle strength 


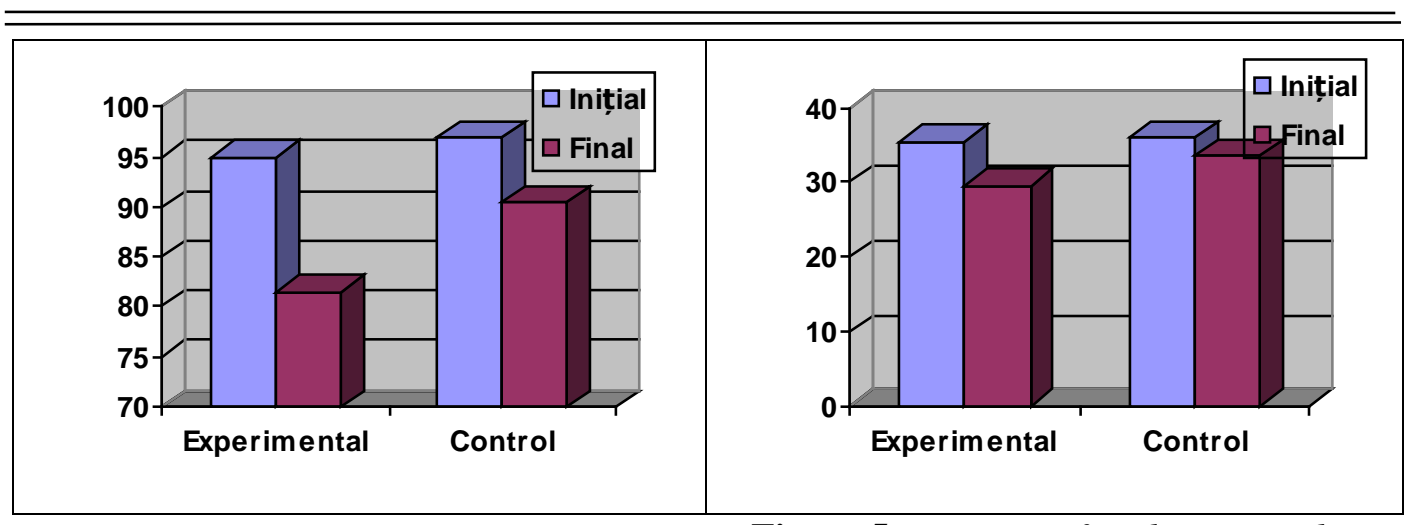

Figure 4. Progress of body weight

Figure 5. Progress of Body Mass Index

The assessment of the self-esteem was done based on the values in Table 2 . The initial self-esteem assessment highlighted the fact that all postpartum women had a low and very low self-esteem. At the end of the experiment, the experimental group subjects had a higher self-esteem for the emotional self and a normal one for the other components (Table 3, Fig. 6), compared to the control group subjects, who remained with a very low self-esteem for the social self and a low one for the other components, which reached normal values (Table 3, Fig. 7).

Table 2. Average scores and standard deviation for self-esteem and its five aspects (Mruk, 2006, p. 52)

\begin{tabular}{cccc}
\hline & Low self-esteem & Normal self-esteem & High self-esteem \\
\cline { 2 - 4 } Self & $\mathbf{- 1} \sigma$ & average & $+\mathbf{+ 1} \sigma$ \\
\hline emotional & 4.60 & 7.40 & 10.20 \\
social & 7.30 & 9.20 & 11.10 \\
professional & 3.80 & 6.40 & 9.00 \\
physical & 5.80 & 8.40 & 11.00 \\
prospective & 6.50 & 8.50 & 10.50 \\
Total Score & 28.00 & 39.90 & 51.80 \\
\hline
\end{tabular}

Table 3. Progress of the average score for self-esteem

\begin{tabular}{lllll}
\hline SUBSCALE & \multicolumn{2}{c}{ Initial testing } & \multicolumn{2}{c}{ Final testing } \\
\cline { 2 - 5 } & $\begin{array}{l}\text { Average score } \\
\text { and assessment - } \\
\text { experimental } \\
\text { group }\end{array}$ & $\begin{array}{l}\text { Average score } \\
\text { and assessment } \\
\text { - control group }\end{array}$ & $\begin{array}{l}\text { Average score } \\
\text { and assessment - } \\
\text { experimental } \\
\text { group }\end{array}$ & $\begin{array}{l}\text { Average score } \\
\text { and assessment } \\
\text { - control group }\end{array}$ \\
\hline Emotional self & 6 (low) & 6.4 (low) & 9 (high) & 7 (normal) \\
Social self & 6.3 (v. low) & 5.5 (v. low) & 9.5 (normal) & 6.5 (v. low) \\
Professional self & 3.6 (v. low) & 3.8 (low) & 7 (normal) & 5.1 (low) \\
Physical self & $4.6(\mathrm{v}$. low) & 5 (v. low) & 8.5 (normal) & 5.8 (low) \\
Prospective self & 6.5 (low) & 6.4 (low) & 8 (normal) & 7 (low) \\
Total Score & 27 (v. low) & 27.1 (v. low) & 42 (high) & 31.4 (low) \\
\hline
\end{tabular}




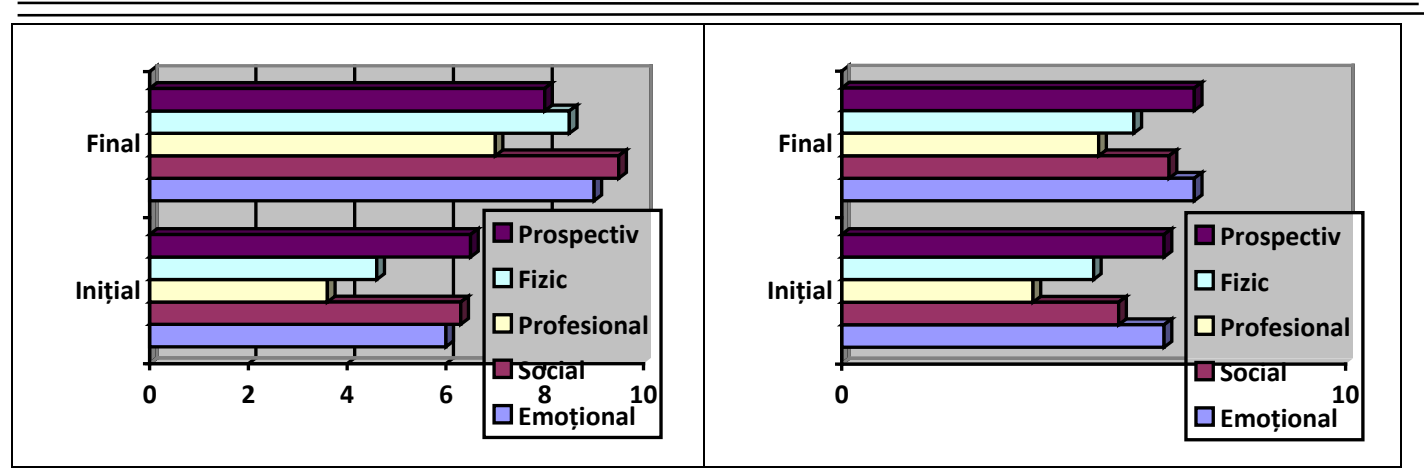

Figure 6. Progress of self-esteem in the experimental group subjects
Figure 7. Progress of self-esteem in the control group subjects

\section{Discussions}

According to some sources, "approximatively 1 out of 8 women has long term postpartum depression (baby blues) during the weeks and months after birth" (Rovența, 2017). According to other sources, "at least half of the young mothers can have the baby blues, but there are experts who say that there are up to $80 \% "$ (Totul despre mame, 2012). Considering the high number of these cases, the authors of this study believe that the improvement of self-esteem and through that the prevention of postpartum depression is a goal that can be reached through the use of massage and complementary techniques.

There are no previous studies referring to the use of massage and complementary techniques for the improvement of self-esteem in new mothers, which is why a comparison between the results of this study and other results is impossible.

\section{Conclusions}

- The use of massage, shiatsu and stretching contributed to the improvement or even curing all disorders that were initially identified during the visual and palpatory examination (poor skin elasticity, sensitivity disorders, stretch marks, circulatory disorders, etc.), and to the considerable improvement of lumbar pains.

- The subjects' range of motion, balance and muscle strength returned to normal parameters due to the effects that massage, shiatsu and stretching had on the functional properties of the muscles.

- Massage, shiatsu and stretching have contributed also to the decrease of the subcutaneous adipose tissue, the weight loss and the decrease of the Body Mass Index.

- As a result of being aware of these effects, after the 8 weeks during which the postpartum women were subjected to the experiment, they have considerably improved their self-esteem, reaching a normal or even high self-esteem, thus preventing postpartum depression.

\section{References}

1. MRUK, C. (2006). Self-Esteem research, theory, and practice: Toward a positive psychology of self-esteem (3rd ed.), New York: Springer, 51-52; 
2. MUNTEANU, I. (2000). Tratat de obstetrică, Bucureşti: Academiei Române, 123;

3. NIȚESCU, V. (2010). Obstetrică şi ginecologie, Bucureşti: Edit. Didactică şi Pedagogică, 105;

4. OBSTRONE, C. (2012, October). http://americanpregnancy.org/first-year-oflife/ postpartum-massage;

5. PAULSON, J.F. (2010). Focusing on depression in expectant and new fathers: prenatal and post-partum depression not limited to mothers. Psychiatry Times. 2010;27(2), http://www.psychiatrictimes.com/major-depressive-disorder/ focusingdepression-expectant-and-new-fathers;

6. ROVENȚA, C.E. (2017, May). Depresia-postpartum-cauze-simptometratament, http://www.csid.ro/lifestyle/psihologie-si-cariera/depresiapostpartum-cauze-simptome-tratament-11721848;

7. TOTUL DEPRE MAME. (2012, February). Depresia postpartum - Simptome si solutii, http://www.totuldespremame.ro/bebelusul-tau/familia-ta/depresiapostpartum-simptome-si-solutii;

8. WISNER, K.L, PARRY, B.L., \& PIONYEK, C.M. (2002). Post-partum Depression. N Engl J Med, 347(3):194.

\title{
Ameliorarea Stimei de Sine la Lăuze prin Folosirea Masajului și a Tehnicilor Complementare
}

\author{
Mârza-Dănilă Doina ${ }^{1}$ \\ Mârza-Dănilă Dănuț Nicu ${ }^{2}$ \\ 1,2 "Vasile Alecsandri" University of Bacău, 157, Calea Mărășești, 600115,Romania
}

Cuvinte cheie: masaj, Shiatsu, stretching, lăuze, stimă de sine

\section{Rezumat}

Am considerat că putem aborda psiho-fizic lăuza prin folosirea masajului, a Shiatsu-lui și a stretching-ului și, ca atare, am structurat și am aplicat programe adaptate la nevoile specifice a 4 (patru) lăuze, rezultatele obținute fiind comparate cu evoluția altor 4 (patru) lăuze, care nu au beneficiat de aceste programe, fiind doar testate inițial și final. Rezultatele au demonstrat faptul că, aplicarea unor programe adaptate de masaj, Shiatsu și stretching, asupra lăuzelor, pe parcursul primelor 8 (opt) săptămâni după naștere (în primele patru săptămâni în trei ședințe pe săptămână, iar în următoarele patru, în două ședințe pe săptămână), contribuie la accelerarea procesului de revenire în parametri normali a indicatorilor fizici și emoționali și la ameliorarea stimei de sine, prevenind cu succes instalarea depresiei postpartum.

\section{Introducere}

Odată cu nașterea copilului, statutul femeii se schimbă brusc, aceasta văzându-se în situația de a face față unei situații noi și de a fi capabilă, în primul rând, să ofere dragoste și afecțiune necondiționate copilului, să răspundă nevoilor 
acestuia de dependență. Pentru o adaptare reușită la noua situație, mama are nevoie de sprijin și de echilibru psihic. Odată cu această trecere bruscă, femeia este în totalitate acaparată de rolul de mamă, negăsind timp, pe perioada lăuziei, pentru a se ocupa de rolul de femeie, soție, fiică, prietenă etc. Din aceste motive, "proaspăta mamă are nevoie de sprijin afectiv din partea familiei și a soțului și a specialiștilor în îngrijiri de sănătate, pentru a duce cu bine la capăt această perioadă și pentru a se afla într-o stare optimă în care să fie capabilă să răspundă nevoilor proprii, ale familiei și ale copilului" (Nițescu, 2010, p. 105).

Nașterea unui copil înseamnă o schimbare totală a priorităților, copilului revenindu-i prim-planul vieții de familie, devenind centrul preocupărilor mamei. Este bine ca soțul să își asume o parte din responsabilitățile îngrijirii copilului și să sprijine mama pentru ca aceasta să își facă timp și pentru sine, să continue să se simtă importantă și să își acorde atenție. Dacă grija pentru copil îi revine în totalitate, va sfârși în scurt timp prin a se simți epuizată și va avea sentimentul că nu este sprijinită.

Lăuzia este o perioadă a fuziunii între mamă și copil, perioada în care se pun bazele relației dintre cei doi. De aceea este important echilibrul psihic al mamei, deoarece copilul are capacitatea de a simți stările emoționale ale mamei și de a reacționa în rezonanță cu ele. "Dacă mama traversează o perioadă de instabilitate emoțională, copilul va fi agitat și va întâmpina o serie de probleme de sănătate și emoționale" (Munteanu, 2000, p. 123). Această etapă postnatală se caracterizează prin începerea procesului de revenire în parametri normali a indicatorilor fizici și emoționali, care au suferit modificări pe parcursul sarcinii. După naștere, datorită modificărilor fizice survenite în timpul sarcinii și în momentul nașterii, stima sa de sine a proaspetei mămici se regăsește diminuată, acest lucru putând contribui considerabil la instalarea depresiei postpartum.

Cercetările referitoare la recuperarea postpartum demonstrează faptul că, "prin folosirea masajului în primele 8 săptămâni postnatal, s-a obținut relaxarea musculaturii, ameliorarea circulației sangvine și limfatice. reducerea stresului, diminuarea durerilor, reducerea straturilor de țesut adipos, ameliorarea elasticității pielii şi reglarea hormonală (scăderea cantității de estrogen și progesteron, reducerea cantităţii de cortizol, creșterea cantității de oxitocină, reducerea cantităţii de dopamină și serotonină, asociate cu depresia, echilibrarea utilizării de către organism a adrenalinei și noradrenalinei)" (Obstrone, 2012).

\section{Material și metode}

S-a pornit de la ipoteza că prin folosirea masajului, a Shiatsu-lui și a stretching-ului se poate contribui la accelerarea procesului de revenire la parametrii funcționali psiho-fizici normali, inclusiv la refacerea stimei de sine și prevenirea instalării depresiei postpartum.

În studiu au fost cuprinse 8 lăuze primipare, cu vârste cuprinse între 25 - 35 ani, care au născut normal, cu 4 dintre ele lucrându-se masaj, Shiatsu și stretching, celelalte 4 fiind doar testate inițial și final, pentru a face posibilă compararea rezultatelor. Pentru a aprecia statusul funcțional psiho-fizic al lăuzelor am folosit, 
inițial și final: examinarea vizuală și palpatorie, evaluarea durerii la nivel lombar cu ajutorul scalei Vass, testul Hettinger, măsurarea greutății corporale și calcularea indicelui de masa corporală și Chestionarul Stima de sine (ETES - L'Echelle Toulousaine d'Estime de Soi) (Mruk, 2006, p. 51).

Lăuzele din grupa experimentală au beneficiat, în primele 4 săptămâni de câte 3 ședințe adaptate de masaj, shiatsu și stretching pe săptămână, iar în următoarele 4 săptămâni de câte 2 ședințe pe săptămână, cu durata aproximativă de 40-50 minute.

\section{Rezultate și discuții}

Pentru prezentarea rezultatelor au fost calculate scorurile medii ale subiecților din cele două grupe, în așa fel încât să fie posibilă compararea lor.

Tabel 1. Rezultatele inițiale și finale ale examinării vizuale și palpatorii a subiecților

\begin{tabular}{|c|c|c|c|c|c|}
\hline \multirow[t]{2}{*}{$\begin{array}{l}\text { Structura } \\
\text { examinată }\end{array}$} & \multirow[t]{2}{*}{$\begin{array}{l}\text { Forma de } \\
\text { examinare }\end{array}$} & \multicolumn{2}{|c|}{$\begin{array}{c}\text { Observații grupa } \\
\text { experimentală }\end{array}$} & \multicolumn{2}{|c|}{ Observații grupa de control } \\
\hline & & Iniţial & Final & Iniţial & Final \\
\hline \multirow[t]{2}{*}{$\begin{array}{c}\text { Pielea și } \\
\text { țesutul } \\
\text { subcutanat }\end{array}$} & $\begin{array}{c}\text { Examinare } \\
\text { vizuală }\end{array}$ & $\begin{array}{l}\text { Piele palidă, } \\
\text { cu vergeturi } \\
\text { Ţesut adipos } \\
\text { subcutanat }\end{array}$ & $\begin{array}{c}\text { Piele cu } \\
\text { aspect normal, } \\
\text { vergeturi } \\
\text { reduse, țesut } \\
\text { adipos redus }\end{array}$ & $\begin{array}{l}\text { Piele palidă, } \\
\text { cu vergeturi } \\
\text { Țesut adipos } \\
\text { subcutanat }\end{array}$ & $\begin{array}{l}\text { Piele cu aspect } \\
\text { aproape } \\
\text { normal, cu } \\
\text { vergeturi, țesut } \\
\text { adipos redus } \\
\text { nesemnificativ }\end{array}$ \\
\hline & $\begin{array}{l}\text { Examinare } \\
\text { palpatorie }\end{array}$ & $\begin{array}{l}\text { Piele uscată, } \\
\text { sensibilă, } \\
\text { flască }\end{array}$ & $\begin{array}{c}\text { Piele elastică, } \\
\text { cu } \\
\text { sensibilitate } \\
\text { normală }\end{array}$ & $\begin{array}{l}\text { Piele uscată, } \\
\text { sensibilă, } \\
\text { flască }\end{array}$ & $\begin{array}{c}\text { Piele cu } \\
\text { elasticitatea } \\
\text { afectată, cu zone } \\
\text { de hiper sau } \\
\text { hiposensibilitate }\end{array}$ \\
\hline \multirow[t]{3}{*}{$\begin{array}{c}\text { Țesutul } \\
\text { muscular }\end{array}$} & $\begin{array}{l}\text { Examinare } \\
\text { vizuală }\end{array}$ & Aspect normal & Aspect normal & Aspect normal & Aspect normal \\
\hline & $\begin{array}{l}\text { Examinare } \\
\text { palpatorie }\end{array}$ & $\begin{array}{c}\text { Musculatură } \\
\text { abdominală } \\
\text { hipotonă }\end{array}$ & $\begin{array}{c}\text { Tonus } \\
\text { muscular } \\
\text { echilibrat }\end{array}$ & $\begin{array}{c}\text { Musculatură } \\
\text { abdominală } \\
\text { hipotonă }\end{array}$ & $\begin{array}{c}\text { Musculatură } \\
\text { abdominală } \\
\text { hipotonă }\end{array}$ \\
\hline & & $\begin{array}{c}\text { Musculatura } \\
\text { paravertebrală } \\
\text { lombară } \\
\text { hipertonă }\end{array}$ & & $\begin{array}{c}\text { Musculatura } \\
\text { paravertebrală } \\
\text { lombară } \\
\text { hipertonă }\end{array}$ & $\begin{array}{c}\text { Musculatura } \\
\text { paravertebrală } \\
\text { lombară } \\
\text { hipertonă }\end{array}$ \\
\hline \multirow[t]{2}{*}{ Circulație } & $\begin{array}{l}\text { Examinare } \\
\text { vizuală }\end{array}$ & $\begin{array}{c}\text { Varice } \\
\text { incipiente și } \\
\text { edeme la } \\
\text { nivelul } \\
\text { membrelor } \\
\text { inferioare }\end{array}$ & Aspect normal & $\begin{array}{c}\text { Varice } \\
\text { incipiente şi } \\
\text { edeme la } \\
\text { nivelul } \\
\text { membrelor }\end{array}$ & $\begin{array}{c}\text { Varice } \\
\text { incipiente încă } \\
\text { prezente }\end{array}$ \\
\hline & $\begin{array}{l}\text { Examinare } \\
\text { palpatorie }\end{array}$ & $\begin{array}{l}\text { Extremități } \\
\text { reci, semnul } \\
\text { godeului } \\
\text { prezent }\end{array}$ & $\begin{array}{l}\text { Temperatură } \\
\text { normală a } \\
\text { extremităților, } \\
\text { semnul } \\
\text { godeului } \\
\text { absent }\end{array}$ & $\begin{array}{l}\text { Extremități } \\
\text { reci, semnul } \\
\text { godeului } \\
\text { prezent }\end{array}$ & $\begin{array}{c}\text { Extremități } \\
\text { reci, semnul } \\
\text { godeului absent }\end{array}$ \\
\hline
\end{tabular}


După cum se poate observa din tabelul 1, la subiecții din grupa experimentală, masajul, shiatsu și stretching-ul utilizate au contribuit la normalizarea aspectelor disfuncționale identificate inițial la nivelul structurilor examinate, pe când la subiecții din grupa de control s-a obținut doar un oarecare grad de recuperare spontană, disfuncțiile restante riscând să se agraveze în timp sau să se transforme în aspect patologice.

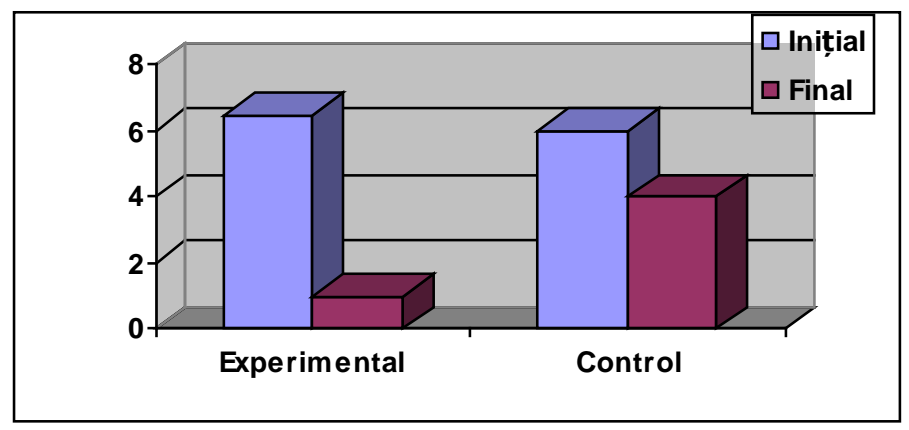

Figura 1. Evoluția durerii lombare la subiecții din cele două grupe

La subiecții din grupa experimentală durerea lombară s-a diminuat până aproape de dispariție, pe când la cei din grupa de control, la sfârșitul celor 8 săptămâni, a fost raportată ca fiind încă prezentă (Fig. 1).

Fără a beneficia de masaj, shiatsu și stretching, lăuzele din grupa de control și-au recuperat mobilitatea articulară, echilibrul și forța musculară într-o măsură mult mai mică decât cele din grupa experimentală (Fig. 2, 3).

Greutatea corporală fiind un indicator care poate contribui mult la scăderea stimei de sine, în cazul în care este peste limitele dorite, a evoluat foarte bine la lăuzele din grupa experimentală, care au pierdut în medie $13,5 \mathrm{~kg}$, comparativ cu cele din grupa de control, care au pierdut în medie $6,5 \mathrm{~kg}$. pe parcursul celor 8 săptămâni cât a durat experimentul (Fig. 4). Această situație s-a reflectat și în evoluția Indicelui de masa corporală (Fig. 5).

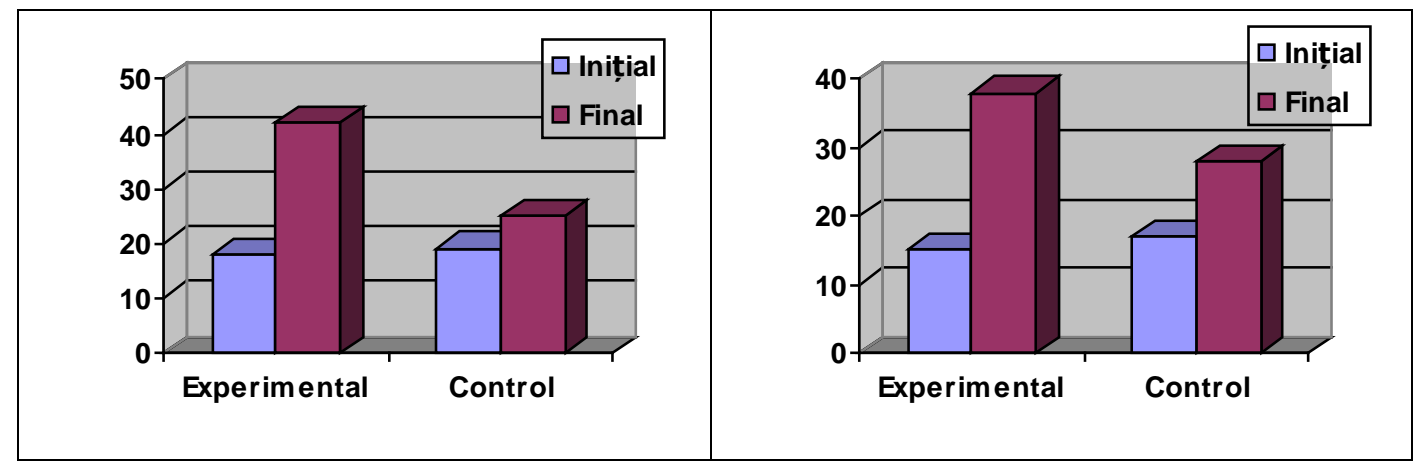

Figura 2. Evoluția mediei punctajelor obținute pentru mobilitate articulară și echilibru
Figura 3. Evoluția mediei punctajelor obținute pentru forța musculară 


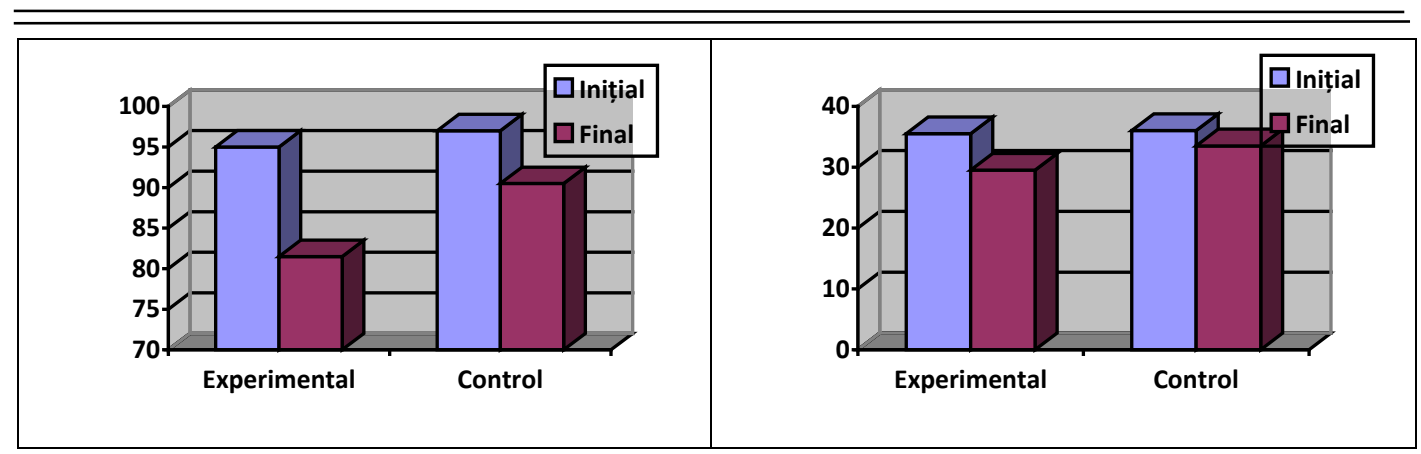

Figura 4. Evoluția greutății corporale

Figura 5. Evoluția Indicelui de masă corporală

Aprecierea stimei de sine s-a realizat în funcție de valorile din tabelul 2. Evaluarea inițială a stimei de sine a scos în evidență faptul că toate lăuzele aveau o stimă de sine scăzută și foarte scăzută la toate componentele. La finalul experimentului, lăuzele din grupa experimentală aveau o stimă de sine crescută la sinele emoțional și normală la celelalte componente (Tabel 3, Fig. 6), comparativ cu cele din grupa de control care au rămas cu stimă de sine foarte scăzută la sinele social și scăzută la celelalte componente, cu excepția sinelui emoțional, unde s-a ajuns la valori normale (Tabel 3, Fig. 7).

Tabel 2. Scorurile medii şi abaterea standard pentru stima de sine şi cele cinci aspecte ale acesteia (Mruk, 2006, p. 52)

\begin{tabular}{cccc}
\hline Sinele & $\begin{array}{c}\text { Stimă de sine } \\
\text { scăzută }\end{array}$ & $\begin{array}{c}\text { Stimă de sine } \\
\text { normală }\end{array}$ & $\begin{array}{c}\text { Stimă de sine } \\
\text { crescută }\end{array}$ \\
\cline { 2 - 4 } & $\mathbf{- 1 \sigma}$ & medie & $+\mathbf{\sigma} \boldsymbol{~}$ \\
\hline emoţional & 4.60 & 7.40 & 10.20 \\
social & 7.30 & 9.20 & 11.10 \\
profesional & 3.80 & 6.40 & 9.00 \\
fizic & 5.80 & 8.40 & 11.00 \\
prospectiv & 6.50 & 8.50 & 10.50 \\
Scor total & 28.00 & 39.90 & 51.80 \\
\hline
\end{tabular}

Tabel 3. Evoluția puntajelor medii obținute pentru stima de sine

\begin{tabular}{lllll}
\hline & \multicolumn{2}{c}{ Testare inițială } & \multicolumn{2}{c}{ Testare finală } \\
\cline { 2 - 5 } \multicolumn{1}{c}{ SUBSCALĂ } & $\begin{array}{l}\text { Punctaj mediu } \\
\text { și apreciere } \\
\text { grupa } \\
\text { experimentală }\end{array}$ & $\begin{array}{l}\text { Punctaj mediu și } \\
\text { apreciere grupa } \\
\text { de control }\end{array}$ & $\begin{array}{l}\text { Punctaj mediu } \\
\text { și apreciere } \\
\text { grupa } \\
\text { experimentală }\end{array}$ & $\begin{array}{l}\text { Punctaj mediu și } \\
\text { apreciere grupa } \\
\text { de control }\end{array}$ \\
\hline Sine emoțional & 6 (scăzută) & 6.4 (scăzută) & 9 (crescută) & 7 (normală) \\
Sine social & 6.3 (f. scăzută) & 5.5 (f. scăzută) & 9.5 (normală) & 6.5 (f. scăzută) \\
Sine profesional & 3.6 (f. scăzută) & 3.8 (scăzută) & 7 (normală) & 5.1 (scăzută) \\
Sine fizic & 4.6 (f. scăzută) & 5 (f. scăzută) & 8.5 (normală) & 5.8 (scăzută) \\
Sine prospectiv & 6.5 (scăzută) & 6.4 (scăzută) & 8 (normală) & 7 (scăzută) \\
Scor total & 27 (f. scăzută) & 27.1 (f. scăzută) & 42 (crescută) & 31.4 (scăzută) \\
\hline
\end{tabular}




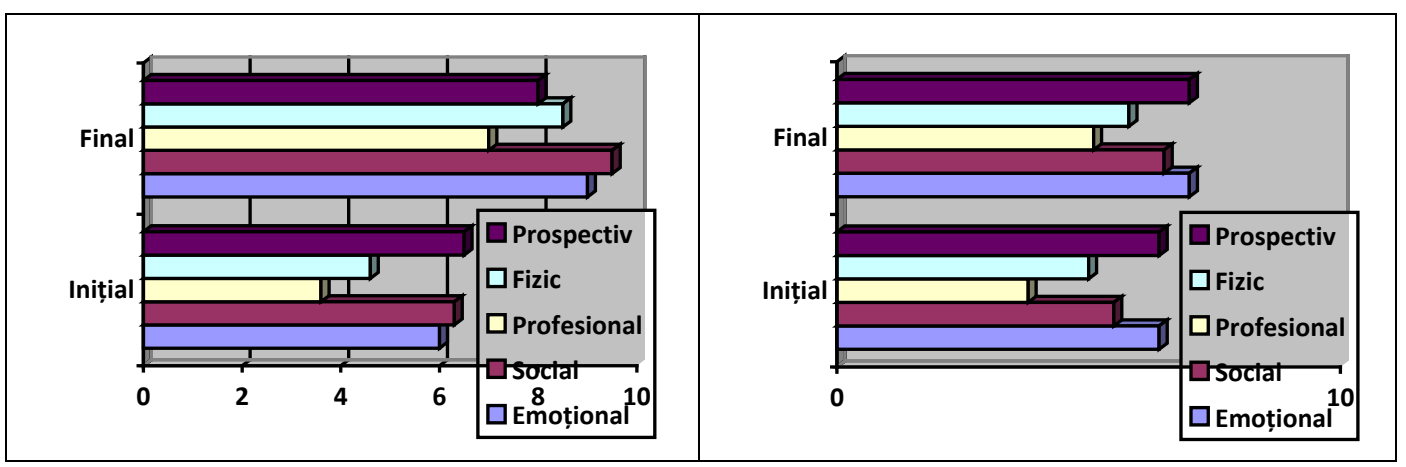

Figura 6. Evoluția stimei de sine la subiecții din grupa experimentală

Figura 7. Evoluția Stimei de sine la subiecții din grupa de control

\section{Discuții}

După unele surse "aproximativ 1 din 8 femei dezvoltă depresie postpartum (baby blues) de lungă durată în săptămânile şi lunile de după naştere" (Rovența, 2017). Conform altor surse "cel puțin jumătate din tinerele mămici pot avea baby blues, dar sunt specialiști care susțin că procentul poate urca de fapt până la 80\%" (Totul despre mame, 2012). Având în vedere incidența crescută a numărului de cazuri, considerăm că ameliorarea stimei de sine și prin aceasta prevenirea instalării depresiei postpartum reprezintă un deziderat care poate fi atins prin folosirea masajului și a tehnicilor complementare.

$\mathrm{Nu}$ există studii anterioare referitoare la folosirea masajului și a tehnicilor complementare în scopul ameliorării stimei de sine la lăuze, motiv pentru care nu este posibilă realizarea unei comparații între rezultatele obținute de noi și alte rezultate.

\section{Concluzii}

- Folosirea masajului, a shiatsu-lui și a stretching-ului a contribuit la îndepărtarea/ameliorarea tuturor tulburărilor identificate inițial la examinarea vizuală și palpatorie (elasticitate scăzută a pielii, tulburări de sensibilitate, vergeturi, tulburări circulatorii etc.) și la ameliorarea considerabilă a durerilor lombare.

- Amplitudinea de mișcare, echilibrul și forța musculară au revenit la parametri normali, datorită efectelor pe care masajul, shiatsu și stretching-ul le-a avut asupra proprietăților funcționale ale mușchilor.

- Masajul, shiatsu și stretching-ul au contribuit, de asemenea, la scăderea masei de țesut adipos subcutanat, scăderea în greutate și scăderea indicelui de masa corporală.

- Ca urmare a conștientizării acestor efecte, după cele 8 săptămâni în care s-a intervenit asupra lăuzelor din grupa experimentală, acestea și-au ameliorat considerabil stima de sine, ajungând la o stimă de sine normală sau crescută chiar la unele componente, prevenindu-se astfel instalarea depresiei postpartum. 